\title{
GEOTHERMAL ENERGY USE FOR THE ADDITIONAL HEAT SUPPLY OF A RESIDENTIAL BUILDING
}

Oleksandra KUZMENKO ${ }^{1 *}$, Kostiantyn DIKAREV ${ }^{1}$, Daniil RODIONOV ${ }^{1}$, Oleksandra MARTYSH ${ }^{1}$, Anar ISKENDEROV $^{1}$, Maryna BABENKO²

\section{Abstract}

To ensure low-energy consumption in new generation energy-efficient houses, the technology of a ground heat exchanger with a heat recovery system is used almost everywhere. However, this technology has not been widely disseminated in Ukraine. The work is aimed at presenting insights from research on the combination of ground heat exchangers with a heat recovery system for building ventilation by analyzing the operational and techno-economic indicators obtained. Current studies permit revealing the optimal configuration of a ground heat exchanger with a heat recovery system for ventilation in a residential building in order to analyze the efficiency of ground heat exchangers with a heat recovery system for ventilation of a residential building in comparison with several conventional ventilation options to assess the main price/ performance ration of the process of constructing a ground heat exchanger with a heat recovery system and to determine the duration of the technological process, the labor-intensive characteristics, and the estimated cost of the technology.

\section{Address}

1 Dept. of Construction Technology, Prydneprovska State Academy of Civil Engineering and Architecture, Dnipro, Ukraine

2 Dept. of Reinforced-Concrete and Masonry Structures, Prydneprovska State Academy of Civil Engineering and Architecture, Dnipro, Ukraine

* Corresponding author: assandra.kuzmenko@gmail.com

\section{Key words}

- Ground heat exchanger,

- Heat recovery.

\section{INTRODUCTION}

The introduction of technological solutions for energy efficiency at the level of the national authorities, single households, and industrial enterprises of Ukraine under international standards remains rather low. Ukraine, which consumes more than 60-70 percent of imported energy in its overall balance sheet, is an energy-dependent country (Ukraine Renewable Energy, 2019).

Therefore, energy conservation and efficiency are priorities in situations involving the energy crisis in the country. In Ukraine, as in most EU countries, more than $34 \%$ of the final energy is consumed by buildings (Ukraine Renewable Energy, 2019). The use of geothermal ventilation can improve energy efficiency in building construction (Ali Sedaghat et al., 2020; Babak Dehghan B. et al., 2020). This technology involves the use of a soil heat exchanger in a mechanical supply and exhaust ventilation system. According to the manu- facturers, the supply air in such a system can be heated from $-24^{\circ} \mathrm{C}$ to $+3{ }^{\circ} \mathrm{C}$. This energy-saving effect can be increased by the use of a heat recovery system in the ventilation system, which makes it possible to take some heat from the exhausted air and return it to a house with supply air with a temperature of up to $+18^{\circ} \mathrm{C}$ even though it is $-24^{\circ} \mathrm{C}$ outside. The introduction of such systems to Ukraine requires extensive parametric studies, the development of engineering methods, and a comprehensive study of the possibilities of their efficient operation.

\section{SURVEY OF THE LITERATURE}

To ensure low energy consumption in new generation energy-efficient houses, the technology of a ground heat exchanger with a heat recovery system is used almost everywhere. 
M. K. Bezrodny and N. O. Prytula (2017) determined the optimal ratios between the characteristics of a horizontal/vertical ground heat exchanger (HGHE / VGHE), such as the length of the pipe of one contour / well depth, pipe diameter and heat carrier velocity in the lower circuit of the heat pumping system (HPS), depending on the operating conditions of the HGHE / VGHE and HPS. These characteristics should ensure the economical velocity of the heat carrier in the lower circuit of the HPS, thus resulting in a minimum specific cost of electricity consumption per TNP of the heat supply in general. In Belgium, (Dumont, 2017) covered the concept of a revolving heat pump of an organic cycle (HP / ORC) and its application in the construction industry. The paper describes the reversibility of positive-displacement machines, which was studied based on a theoretical comparison showing the compiled experimental results of four different expander compressor technologies. The heat pump of the Rankin cycle is described, a parametric investigation of which was carried out to monitor the performance of the system in a wide range. The effect of different lights and device profiles, battery integration, roof slope angles and locations were taken into account. In addition, a technical and economic comparison with one of the most mature technologies for generating positive energy, namely photovoltaic (PV) panels combined with a heat pump in a passive house, was being carried out.

In Latvia, A. Zandeskis et al. (2015) set out high standards of energy efficiency and stability and a perfect overview of the technologies and methods for a ventilation air heat project as key aspects of the high energy and environmental indexes of buildings located in a cold climate. The results of this work are more relevant in a building where space heating consumes a large part of the building's energy balance. The right design and control strategy, heat recovery, renewable sources, and waste heat are the main aspects to be considered.

In Italy, Diana Dagostino et al. (2016) have studied the energy-saving effects that can be obtained by means of air-conditioning systems provided by the corresponding ground-air heat exchangers and/or air exchangers for two different Italian climates, i.e., Palermo, a city in southern Italy, which is characterized by hot summers and mild winters, and Milan, a city in northern Italy, which is characterized by hot summers and cold winters. They analyzed the dynamic energy efficiency of a building with reference to the same designed office space with or without two types of heat exchangers. The article estimates the reductions in $\mathrm{CO}_{2}$ emissions and the payback periods of the two technologies.

Suszanowicz D. and Pietkun-Greber I., (2017) demonstrated the efficacy of different types of ventilation in a block of flats, with a special emphasis on natural ventilation, which is a well-known solution in Polish houses. The efficiency of ventilation systems and their influence on the main properties of air quality, i.e., the concentration of carbon dioxide, relative humidity, and temperature, were presented. Their studies showed that natural ventilation for a block of flats is not effective and should be replaced by mechanical ventilation, preferably by mechanical ventilation with energy recovery.

Suszanowicz D., (2018) dealt with the results of heat losses from various types of residential units using ventilation systems. An investigational study of ventilation systems of various types was carried out and parameters of the exhaust air were determined. A model of the heat losses from the exhaust air through air ducts to the environment was developed.

The studies were carried out on three experimental building ventilation systems, i.e. gravitational, mechanical, and supply and exhaust systems with energy recovery. This study proved that the natural ventilation in residential units functions by increasing the airflow into the building, which leads to significant heat leakage from the buildings during the heating season.

\section{MATERIALS AND METHODS}

\subsection{Specifics of design and technological solutions and climactic conditions of the building selected}

For carrying out the analytical study, a two-story residential dwelling located in Dnipro, Ukraine, was selected.

Fig. 1 shows the building with its complex rectangular shape. The building is designed was a basement.

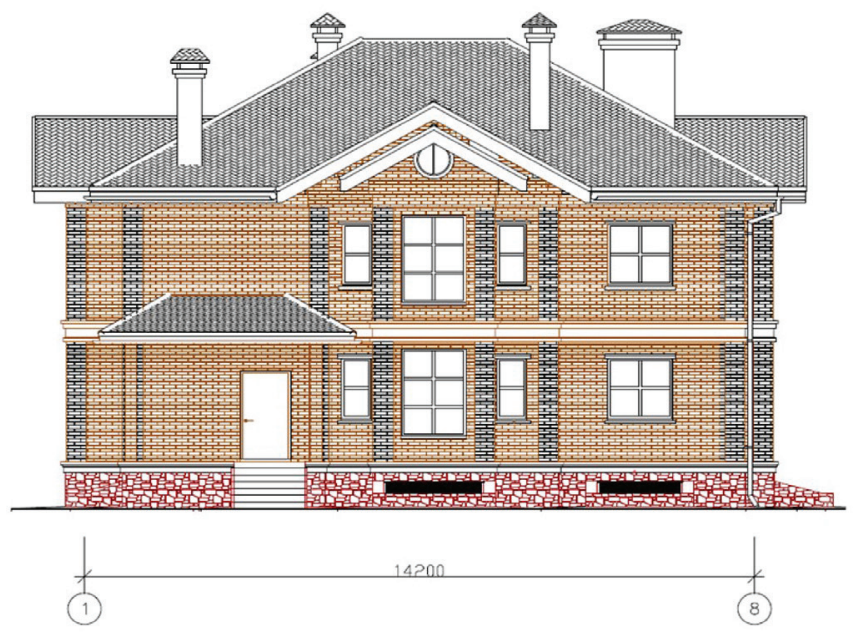

Fig. 1 The front facade of a residential dwelling in 1-8 axes

Building specifications:

- Number of storeys - 2 storeys;

- Overall floorage - $\mathrm{S}=290.7 \mathrm{~m} 2$;

- Total structural volume $\mathrm{V}=1586.5 \mathrm{~m}^{3}$;

- Living area $\mathrm{S}=172.1 \mathrm{~m}^{2}$;

- Area of non-residential premises, $\mathrm{S}=112.4 \mathrm{M}^{2}$;

$-1^{\text {st }}$ floor area $\mathrm{S}=120.1 \mathrm{~m}^{2}$;

$-2^{\text {nd }}$ floor area $\mathrm{S}=84.5 \mathrm{~m}^{2}$;

- Cellar space $\mathrm{S}=120.1 \mathrm{~m}^{2}$.

Geometrical parameters:

$-1^{\text {st }}$ floor height is $3.00 \mathrm{~m}$;

$-2^{\text {nd }}$ floor height is $3.00 \mathrm{~m}$;

- Basement floor height is $2.70 \mathrm{~m}$;

- High / maximum mark is $+9.95 \mathrm{~m}$;

- Dimensions in the 1-8 axes are $14.20 \mathrm{~m}$; in A-I, 11 axes are $70 \mathrm{~m}$.

The building has three levels. On the 1st floor, there are a kitchen, a dining room, a living room, a guest room, an office, and two bathrooms. The second floor has three bedrooms, a nursery, an office and a bathroom. In the basement, there are a wardrobe, an atelier, a boiler, a storeroom, a billiard room, a storeroom, a shower, and a bathroom. Communication between the main premises is provided by the halls.

The outer enclosure structures are three-layer walls. The inner layer is a $250 \mathrm{~mm}$ - thick bearing brick wall; the middle layer is Rockwool Light BATTS mineral wool boards, the thickness of which is taken into account; the outer layer is a brick façade with a thickness of $120 \mathrm{~mm}$. The interior surfaces of the walls are plastered.

The sanitary and hygienic requirements of the home are as follows:

- indoor air temperature in the living areas is not less than $20^{\circ} \mathrm{C}$;

- the humidity of the indoor air is 55-60\%.

The building is located in the 1st climatic district of Ukraine. Due to this physical and climatic situation, the city of Dnipro belongs to a zone which is characterized by a temperate continental climate. 
The geographical characteristics of Dnipro are:

- the latitude is $48^{\circ} 27 \mathrm{n} .1$.;

- the average altitude is $169 \mathrm{~m}$;

- the relief is plain;

- the prevailing wind direction in the warm and cold periods of the year is NW;

- vegetation: trees, bushes.

According to the territorial zoning of Ukraine DBN V.2.6-31: 2016, Dnipro belongs to the first temperature zone. This zone is characterized by the following average winter and summer ambient temperatures:

- The average annual temperature is $+8.7^{\circ} \mathrm{C}$;

- The hottest daily temperature is $+30^{\circ} \mathrm{C}$;

- The average temperature of the coldest five days is $-24^{\circ} \mathrm{C}$;

The ground snow load is $1500 \mathrm{~Pa}$; Dnipro is in the $\mathrm{V}$ region; the wind pressure is $450 \mathrm{~Pa}$ for the II region. The wind speed is $\mathrm{V}=3.7-4.7 \mathrm{~m} / \mathrm{s}$.

In the cold and hot periods of the year, the wind in the northwest direction prevails. The number of days with a strong wind of $12 \mathrm{~m} / \mathrm{s}$ is 15 days per year.

\subsection{Specifics of the technological solutions for a geothermal ventilation system with a heat recovery system}

The design of the external walls of modern energy-efficient houses makes it possible to prevent the uncontrolled flow of outdoor air into the premises. In order to provide energy-efficient houses with fresh air and remove polluted air, it is necessary to use mechanical ventilation, which permits maintaining the necessary parameters of the microclimate in the premises. To save thermal energy in ventilating systems that are used for the heating of external air, it is appropriate to apply "air-air" heat exchangers and ground heat exchangers. «Airair» heat exchangers are intended for heating the external intake of air by the heat of the exhaust air. In passive houses, it is recommended to install heat recovery systems with a recovery rate of more than $75 \%$ (Savchenko et al., 2009). Ventilation systems in which ground heat exchangers are used for the first heating of the external supply air are called geothermal systems (Fig 2.).

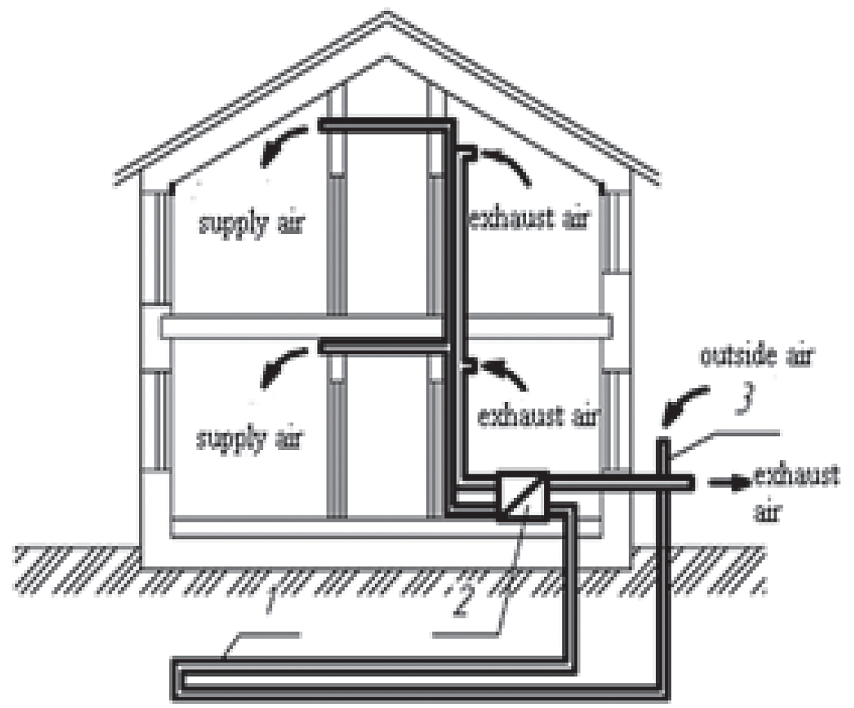

Fig. 2 Structural scheme of the geothermal ventilation of a passive house: 1 - horizontal ground heat exchangers, 2 - recoverer, 3 intake ventilation shaft
The principles of geothermal ventilation during the cold period of the year are as follows. Air having a temperature $t_{\text {ext }}$ is conducted to the input of the ground heat exchanger, and then it gains the soil heat through the wall of the heat exchanger. As a result, the external supply air is heated to $t_{\mathrm{s}}$ and transmitted into the room. If necessary, air with a temperature of $t_{s}$ is heated in the heat recovery system by the heat of the exhaust air up to the necessary temperature of the inside air $t_{\text {ins }}$ (Nakashidze, 2018).

The underground heat exchangers for ventilation are divided into three main groups: gravel (ductless), tubular (duct), and membraneless. In any scheme, the main air supply channel should be connected to the ventilation, and a mechanism is provided for switching from the use of the heat exchanger to the use of the direct airflow from the street (P. Kachur, 2016). A soil duct heat exchanger is a system of pipes laid in the ground below the frostline that acts as a heat exchanger between the soil and the air passing through the pipelines. The diameter of the pipes is from 200 to $400 \mathrm{~mm}$ (sometimes larger, depending on the volume of the building).

The pipelines provide heating of the intake air into a house in the winter and cooling during the hot season of the year. Such a system not only allows for a reduction in the thermal energy consumption but also considerably improves comfort in the home. Heat recovery is the process of the heat returning and the process of getting it back. It is necessary to return the heat we collect from all the premises to the house (Mileykovsky and Kotelkov, 2018).

The main element of a supply and exhaust ventilation unit with heat recovery is a surface-type plate recuperative heat exchanger. This makes it possible to use the heat of the exhaust air, which is removed from the premises by the exhaust fan, to heat the outdoor air conducted into the room by an air supply fan. The efficiency of the heat transfer directly depends on the state of the surface that is transmitting the heat. To protect it against pollution, intake and exhaust air filters must therefore be used (Fig. 3).

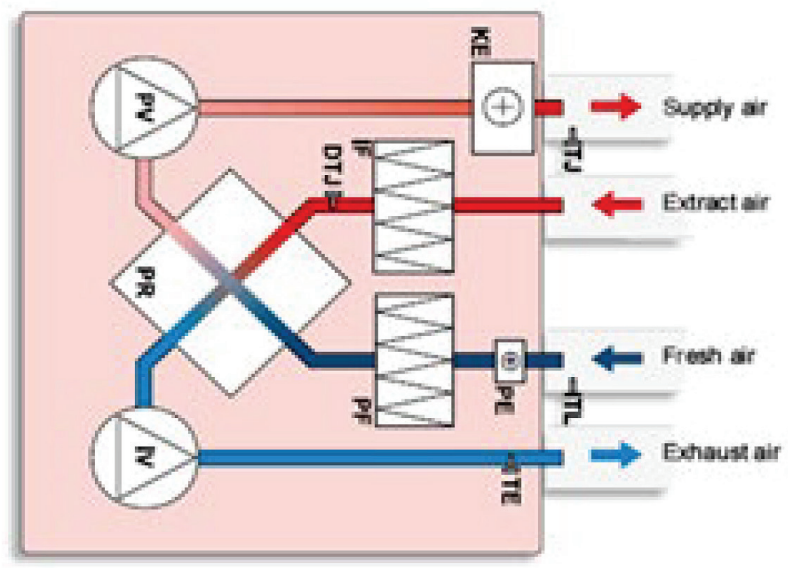

Fig. 3 Scheme of supply and exhaust ventilation unit with heat recovery with a surface-type plate recuperative heat exchanger

For a further analytical investigation, we have chosen the Recair RS300-400-000 recuperation heat exchanger with characteristics specified in Tab. 1.

\subsection{The technology of the construction of horizontal ground heat exchangers}

The assembling of horizontal ground heat exchangers is carried out in trenches. The choice of mechanisms depends on the soil conditions. The horizontal heat exchanger technology provides the fol- 
Tab. 1 Characteristics of the Recair RS300-400-000 heat exchanger

\begin{tabular}{|c|l|c|l|c|}
\hline № & \multicolumn{1}{|c|}{ Characteristics of the (fresh) air supply } & Value & Characteristic of the exhaust air & Value \\
\hline 1. & Supply (fresh) air-flow & $750 \mathrm{~m}^{3} / \mathrm{h}$ & Exhaust air-flow & $750 \mathrm{~m}^{3} / \mathrm{h}$ \\
\hline 2. & The temperature at the inlet & $-14.1^{\circ} \mathrm{C}$ & The temperature at the inlet & $20^{\circ} \mathrm{C}$ \\
\hline 3. & Relative humidity at the inlet & $38 \%$ & Relative humidity at the inlet & $50 \%$ \\
\hline 4. & The temperature at the outlet & $16.02^{\circ} \mathrm{C}$ & The temperature at the outlet & $1.06^{\circ} \mathrm{C}$ \\
\hline 5. & Relative humidity at the outlet & $4 \%$ & Relative humidity at the outlet & $100 \%$ \\
\hline
\end{tabular}

Tab. 2 Ground heat exchanger calculations

\begin{tabular}{|c|c|c|c|c|}
\hline № & Pipe & Length of the pipe, m & Quantity & Diameter, mm \\
\hline 1. & Rehau Awadukt Thermo DN 315 & 6 & 13 & 315 \\
\hline 2. & Rehau Awadukt Thermo DN 315 & 3 & 2 & 315 \\
\hline 3. & Rehau Awadukt Thermo DN 315 & 1 & 3 & 315 \\
\hline
\end{tabular}

lowing sequence of actions: first, the heat exchanger route is marked, and the home entry point is planned. During the excavation of the trenches, the soil is removed, and a pipeline is placed on the bottom of the trenches. The pipeline is banked up with soil every few meters. Then, the pipe is inserted into a specially made hole in the basement. A pressure test of the pipeline and the backfilling of the trench should be carried out after the full installation. Moreover, the first 15 $\mathrm{cm}$ should be manually banked up. Further backfilling is done by a bulldozer or other machine. Tab. 2 presents a summary of the ground heat exchanger calculations.

The overall length of the ground heat exchanger is $94 \mathrm{~m}$ (including distributors and adapters). The scheme of the disposition of the ground heat exchanger in the excavation is presented in Fig. 4.

\subsection{Thermotechnical calculation of the construction of the barrier}

The "Thermal Insulation of Buildings" method described in the standard DBN B.2.6-31: 2016 (Thermal insulation of buildings, 2016) was used for the thermotechnical calculations of the walls The aim was to determine the thickness of the insulation layer in the enclosure that will meet the following thermotechnical requirement (1):

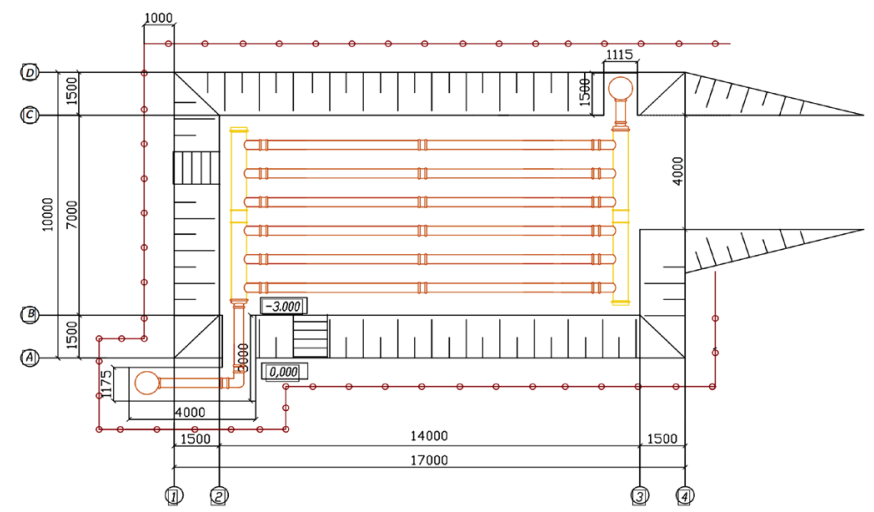

Fig. 4 The scheme of disposition of the ground heat exchanger in the excavation

$$
R_{\Sigma} \geq R_{q \min }
$$

where $R_{\Sigma}$ is the total thermal resistance of the non-transparent insulating structure or non-transparent part of the barrier structure and the given resistance of the heat transfer of the translucent barrier structure, $\mathrm{m}^{2} \cdot \mathrm{K} / \mathrm{W}$;

$R_{q \min }$ is the minimum required heat transfer resistance of a non-transparent barrier structure or non-transparent part of a barrier structure; the minimum value of the heat transfer resistance of a translucent barrier structure is $\mathrm{m}^{2} \cdot \mathrm{K} / \mathrm{W}$;

The minimum allowable heat transfer resistance of barrier structures of residential units $\left(\mathrm{R}_{\mathrm{q} \text { min }}\right)$ is defined in Table 3 (Thermal insulation of buildings, 2016). The city of Dnipro is situated in the first temperature zone; therefore, the barrier structures should have the following minimum values $R_{q}$

- external walls $-3.3 \mathrm{~m}^{2} \cdot \mathrm{K} / \mathrm{W}$;

- basement floor $-3.75 \mathrm{~m}^{2} \cdot \mathrm{K} / \mathrm{W}$;

- unheated attic slab $-4.95 \mathrm{~m}^{2} \cdot \mathrm{K} / \mathrm{W}$.

The $R_{\Sigma}$ value is determined by the formula (2):

$$
R_{\Sigma}=\frac{1}{\alpha_{\mathrm{int}}}+\sum R_{i}+\frac{1}{\alpha_{\text {ext }}},
$$

where $\alpha_{\text {int,ext }}$ are the values of the heat transfer coefficients of the internal and external surfaces of the barrier structures, which are determined from Annex E (Thermal insulation of buildings, 2016);

$\Sigma \mathrm{Ri}$ is the resistance to heat transfer of all the structural layers $\left(\mathrm{m}^{2}\right.$ - $\mathrm{K} / \mathrm{W}$ ), which is determined by the formula (3):

$$
R_{i}=\frac{\delta_{i}}{\lambda_{i}}
$$

where $\delta_{i}$ is the thickness of the layer of the material $\mathrm{m}$; $\lambda_{i}$ is the thermal transmission coefficient of the material.

The specification of the elements of the barrier structures is given in Tab. 3.

The results of the thermotechnical calculations of the barrier structures are given in Tab. 4.

Based on the results of the calculations, we can conclude that the calculated heat transfer resistance exceeds the thermal resistance required, so the condition holds. 
Tab. 3 The specification of the elements of the barrier structures

\begin{tabular}{|c|c|c|c|c|}
\hline № & Barrier Structure & Name of Layer & $\begin{array}{c}\text { Thickness } \\
\delta, \mathbf{m}\end{array}$ & $\begin{array}{l}\text { Thermal Transmission } \\
\text { Coefficient } \lambda_{b}, W / m K\end{array}$ \\
\hline \multirow{4}{*}{1.} & $\begin{array}{l}\text { External wall construction } \\
\begin{array}{cccc}1 & 2 & 3\end{array}\end{array}$ & 1. Sand-cement bonding plaster & 0.02 & 0.81 \\
\hline & & 2. Sand-lime bearing brick & 0.25 & 0.87 \\
\hline & & $\begin{array}{l}\text { 3. Insulant, Rockwool Light BATTS } \\
\text { mineral wool boards }\end{array}$ & 0.1 & 0.037 \\
\hline & 20 250 100 120 & 4. Sand-lime hollow lining brick & 0.12 & 0.52 \\
\hline \multirow{5}{*}{2.} & \multirow[t]{5}{*}{ Floor construction of a basement } & 1. Ceramic tiles & 0.01 & 0.5 \\
\hline & & 2. Sand cement screed & 0.035 & 0.9 \\
\hline & & 3. Monolithic reinforced concrete slab & 0.2 & 1.69 \\
\hline & & 4. Insulation & 0.2 & 0.034 \\
\hline & & 5. Expanded polystyrene (EPS)/ & 0.1 & 0.45 \\
\hline \multirow{3}{*}{3.} & \multirow{3}{*}{ Floor cons } & $\begin{array}{l}\text { 1. Expanded polystyrene insulant } \\
\text { (EPS)/foam Penoplex polystyrene }\end{array}$ & 0.2 & 0.037 \\
\hline & & 2. Monolithic reinforced concrete slab & 0.2 & 1.69 \\
\hline & & 3. Drywall ceiling construction & 0.1 & 0.15 \\
\hline
\end{tabular}

3.5 Analysis of loads on the heating system using a ground heat exchanger with a heat recovery system and in the absence of the mentioned energy-efficient ventilation system

In order to compare the heating system loads, it was agreed to consider four variants for the configuration of the ventilation system: passive (through the windows and doors), mechanical (supply and exhaust ventilation), mechanical ventilation with a ground heat exchanger, and mechanical ventilation with a ground heat exchanger and a heat recovery system.

The calculations were carried out based on the instructive methodological regulations (O. P. Lyubarets et al., 2016), (Heating, ventilation and air conditioning, 2013), (Energy performance of buildings, 2017), and (DSTU B EN 15251: 2011, 2012).

According to (DSTU B EN 12831: 2017, 2017), the heat load of a room for the heating system is determined according to the thermobalance formula (4) of the room:

Tab. 4 The results of the thermotechnical calculations of the barrier structures

\begin{tabular}{|c|l|c|c|}
\hline № & Barrier Structure & $\begin{array}{c}\text { Required } \\
\text { Rmin, } \\
\mathrm{m}^{2} \mathrm{~K} / \mathrm{kW}\end{array}$ & $\begin{array}{c}\text { Calculated } \boldsymbol{R}_{\Sigma} \\
\mathrm{m}^{2} \mathrm{~K} / \mathrm{kW}\end{array}$ \\
\hline 1. & External wall construction & 3.3 & 3.406 \\
\hline 2. & Floor construction of a basement & 3.75 & 6.59 \\
\hline 3. & Floor construction of an attic & 4.95 & 5.72 \\
\hline
\end{tabular}

$$
\Phi H L, i=\Phi T, i+\Phi V, i+\Phi R H, i+\Phi Q, i,
$$

where: $\Phi T, i$ is the transmission loss through the enclosing structures of the premises; $\Phi \mathrm{V}, \mathrm{i}$ is the ventilation heat loss to heat the infiltration air entering the premises; $\Phi R H, i$ is the additional compensatory thermal power for the discontinuous heating system, taking into account the temporary heating effect of the premises (it was overlooked due to the absence of this factor); $\Phi \mathrm{Q}, \mathrm{i}$ - other possible routine heat losses (with the sign "+") or heat inflow (with the sign "-") in the heated space (from the equipment and people), W.

\section{RESULTS AND DISCUSSION}

\subsection{Comparison of the thermal capacity, depending on the configuration of the ventilation system}

Each room was considered, taking into account the calculated thermal resistance of all the barrier structures and the internal temperature of $+20^{\circ} \mathrm{C}$. The external design temperature was the average temperature of the five coldest days i.e., $-24^{\circ} \mathrm{C}$. The transmission losses were influenced by the orientation factor of the room in relation to the sides of the walls. To calculate the heating system loads, an Excel document was created, where the method of determinating the heat loss and thermal capacity of the heating system was implemented (Determination of thermal capacity of the heating system, 2016).

After the calculations, four results pertaining to the thermal capacity of the heating system were obtained. The first was for a ventilation system with a heat recovery system and a ground heat exchanger; 


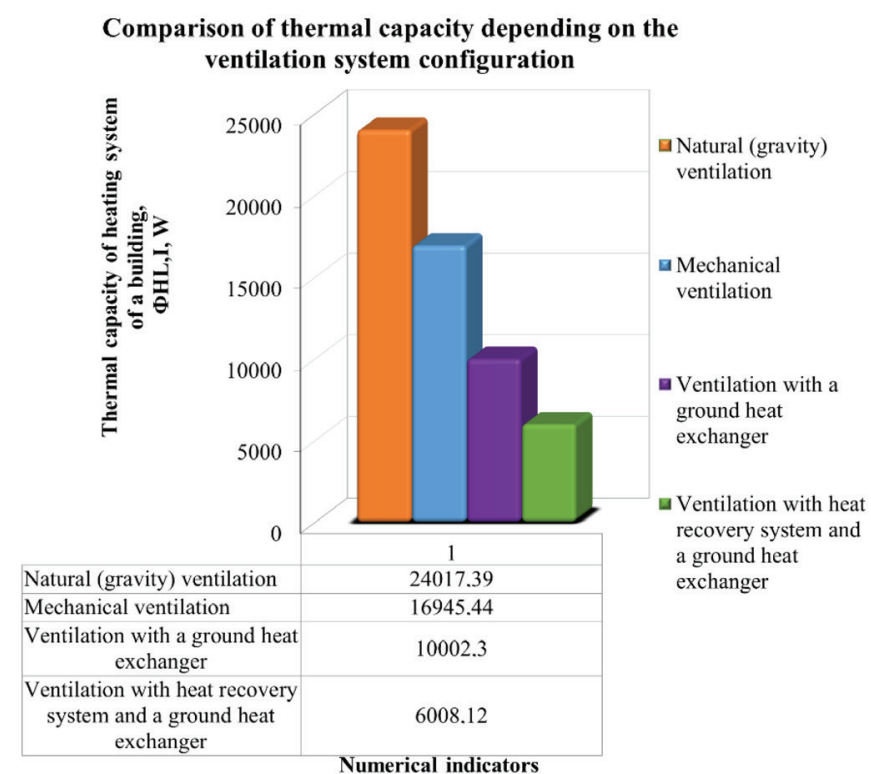

Fig. 5 Comparison of thermal capacity depending on the ventilation system configuration

the second was for ventilation only with a ground heat exchanger; the third was for normal mechanical ventilation; and the fourth was a natural ventilation system. The numerical calculation data are presented as a diagram in Fig. 5.

After having analyzed the results, it can be seen that the ventilation system with a heat recovery system and ground heat exchanger shows the lowest thermal power indicators. A system with only a ground heat exchanger is $67 \%$ more powerful than the previous system, and the system of mechanical ventilation requires $182 \%$ more heat energy than the first system. However, if the room is ventilated through windows and doors, the difference in thermal power between the first and the last variant is 301 percent (Fig.6).

The option of using only mechanical inflow exhaust ventilation reduces the thermal capacity for heating by a factor of 1.4 compared to natural ventilation. The option of mechanical ventilation with only a ground heat exchanger ensures that the heating capacity of the heating system is 2.4 times lower than in the case of natural ventilation. This is due to the increase in the inlet temperature from $-24^{\circ} \mathrm{C}$ to $+3^{\circ} \mathrm{C}$

The thermal capacity of the heating system was found to be 4 times higher in the classical natural ventilation than in the combined geothermal ventilation system with the heat recovery system. The reason for this efficiency consists in the increase of the inlet temperature from $-24^{\circ} \mathrm{C}$ to $+18^{\circ} \mathrm{C}$ by pre-heating the air under the ground and the subsequent post-heating with the exhaust heat in the heat recovery system. Therefore, the last variant was chosen as the most energy-efficient technology that met our requirements.

\subsection{Analysis of the techno-economic indicators of the ground heat exchanger circuit}

The calculations of the length of the ground heat exchanger were carried out using a specialized online calculator (calculator for calculating the ground heat exchanger), and it was determined that the length of the ground heat exchanger at a depth of $3 \mathrm{~m}$ should be about $80 \mathrm{~m}$. After analyzing the market for equipment and materials, pipes and Awadukt Thermo of Rehau polypropylene components were selected, as well as the Slimstar 750-EC of the Aerostar air handling unit was selected. The total cost of the materials lequipment was 703, $100 \mathrm{UAH}$ (21, $469 \mathrm{EUR})$

\section{Ratio of thermal power indicators as a percentage}

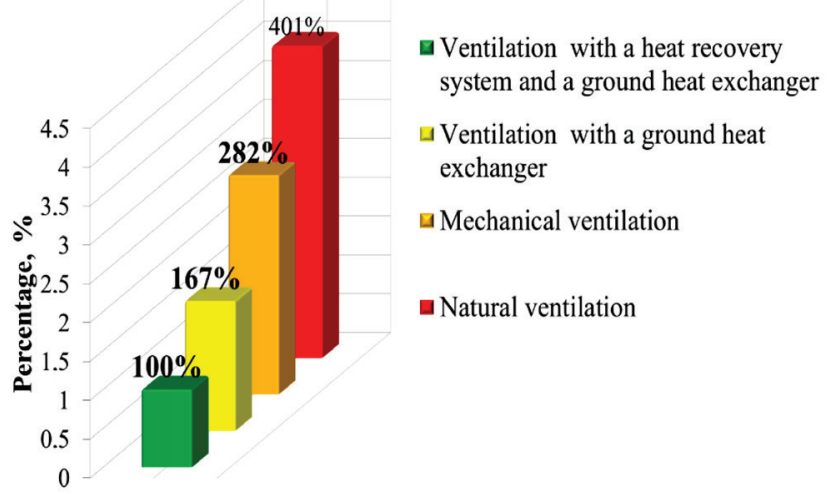

Fig.6 The ratio of thermal power indicators as a percentage

Since a building of $290.7 \mathrm{~m}^{2}$ requires a large volume of air, it needs a large number of pipes. In such cases, the pipe laying is usually done according to the Tihelman scheme with the purpose of reducing the area (Fig.7).

For the following analysis of the technical and economic indexes, a technological map for the arrangement of the ground heat exchanger circuit was developed.

The work considered included:

1. Site planning.

2. Excavation of pit.

3. Placement and compaction of sand base.

4. Mounting of the pipes by a crane into the excavation pit.

5. Pipelaying in the designed position.

6. Building-in of PP pipes through the walls of the building.

7. Soil replenishment.

8. Manual layer-by-layer tamping.

9. Hydraulic pressure test of pipelines.

10. Excavation backfill.

11. Soil compaction with electrical rammers

As a result of the technological map calculations (D. Rodionov, 2020) for the external circuit of the geothermal ventilation system, the following data was obtained:

The total labor intensity of the excavation work was 4.68 machine - shifts and 0.44 man-days. The wages for the works performed were 2.370 UAH (72.37 EUR). The amount of labor required for the installation of the ground heat exchanger was 2.42 machine - shifts and 19.63 man-days. The wages for the works performed was $9.049 \mathrm{UAH}$ (276.3 EUR). For the excavation backfilling, the labor intensity was 1.95 man-days and 1.25 machine - shifts. The wages for the works performed was 1278 UAH (39 EUR). The amount of time for the external circuit installation of the geothermal ventilation system was 7 days. The schedule of work to be performed was designed in the MS Project.

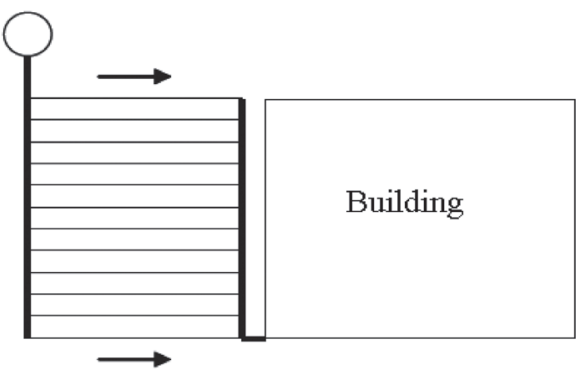

Fig. 7 Tigelman Pipe Laying Scheme 


\section{CONCLUSIONS}

The article analyzes the technical parameters for a geothermal ventilation system based on a ground heat exchanger and a heat recovery system for a $290.7 \mathrm{~m}^{2}$ residential building. To compare the thermal capacity of the heating system, four ventilation systems were selected: one with a heat recovery system and a ground heat exchanger, one with a ground heat exchanger only, one with normal mechanical ventilation, and one with natural ventilation. It was determined that the thermal capacity of the heating system is 4 times higher in the natural ventilation than in the combined geother- mal ventilation system with the heat recovery system. The reason for such efficiency consists of the increase of the inlet temperature from $-24^{\circ} \mathrm{C}$ to $+18^{\circ} \mathrm{C}$ by pre-heating the air under the ground and subsequent post-heating with the exhaust heat in the heat recovery system. A disadvantage of this solution is the high cost of the materials. The analysis of the labor intensity, duration, and wages shows the availability of the specified technology and the relative simplicity of implementation in Ukrainian conditions. In further studies, it is planned to consider the energy consumption of the combined ground heat exchanger system and the heat recovery system during the heating season. 


\section{REFERENCES}

Bezrodny, M. K. - Prytula, N. O. (2017) Optimal characteristics of ground heat exchangers for heat pump heating systems. "Kharkiv Polytechnic Institute", Bulletin of the National Technical University "KhPI" : coll. works. Ser. : Power and Heat Engineering Processes and Equipment. - Kharkiv : HТУ “ХПI”, 2017. - № 8 (1230), pp. 41-48.

Calculator for calculating the ground heat exchanger. // [Electronic resource] / Available at: http://sdinfo.ru.

D’Agostino, D. - Marino, C. - Minichiello, F. (2016) The use of earth-to-air and air-to-air heat exchangers for different Italian climates. Int. J. Heat Technol, 34, pp. 287-294.

DBN B.2.5-67: 2014 (2013) Heating, ventilation and air conditioning./ Ministry of Regional Development and Housing of Ukraine.- K .: SE "Ukrarchbudinform" Ministry of Construction of Ukraine, - 141 pp. - (Building Standards of Ukraine). (ДБН В.2.5-67:2014 Опалення, вентиляція та кондиціонування)

Dehghan B. - Wang, L. - Motta, M. - Karimi, N. (2020) Modelling of waste heat recovery of a biomass combustion plant through ground source heat pumps: development of an efficient numerical framework. Applied Thermal Engineering, 166, 114625.

DSTU B EN 12831:2017 (2017) Energy performance of buildings - Method for calculation of the design heat load. - [Entered into force from 15-12-2017]. - K.: Ministry of Regional Development, Construction, and Housing Services, 2017. 32pp. - (Building Standards of Ukraine.), (ДСТУ ЕN 128311:2017 Енергоефективність будівель. Метод розрахунку проектного теплового навантаження)

DSTU B EN 15251: 2011 (2012) Estimated parameters of the microclimate of the premises for the design and evaluation of energy performance of buildings in relation to air quality, thermal comfort, lighting and acoustics. - [Entered into force from 01-012013]. - K.: Ministry of Regional Development, Construction, and Housing Services, 2012. - 71 pp. - (Building Standards of Ukraine.), (ДСТУ Б ЕN 15251:2011. Розрахункові параметри мікроклімату приміщень для проектування та оцінки енергетичних характеристик будівель по відношенню до якості повітря, теплового комфорту, освітлення та акустики).

Dumont, O. (2017) Investigation of a heat pump reversible in an organic Rankine cycle and its application in the building sector. (Doctoral dissertation, Université de Liège, Liege, Belgique), pp. 30-38.

Kachur, P. (2016) Energy saving in the housing stock: problems, practice, prospects. Handbook, Kyiv, pp. 23-56.
Lyubarets, O. P. - Senchuk, M. P. - Lyubarets, V. O. (2016) Heating. Methodical instructions. Determination of thermal capacity of the heating system. For students majoring in "Construction and Civil Engineering." (specialization "Heat and gas supply and ventilation") - K .: KNUCA, - 34 pp.

Mileykovsky, V. O. - Kotelkov, L. M. (2018) Ventilation of an individual house. Dnipro

Теплова ізоляція будівель : ДБН В.2.6-31:2016. Thermal insulation of buildings :DBN V.2.6-31:2016. - [Entered into force from 08-07-2016]. - K.: Ministry of Regional Development, Construction, and Housing Services, 2017. - 33 pp. - (Building standard of Ukraine.).

Nakashidze L. V. (2018) Energy-efficient indoor climate systems based on the use of solar and environmental energy. Vidnovluvana energetika. Renewable energy, Kyiv, Ukraine, pp. 21-30.

Rodionov, D. (2020) Master diploma thesis. Efficiency of use of ground heat exchangers with a heat recovery system for ventilation of a residential building. Scientific supervisor: O. Kuzmenko. Prydneprovska State Academy of Civil Engineering and Architecture, Dnipro, 2020. - 111 pp.

Savchenko, O. O. - Zhelykh, V. M. - Dudnik, K. A. - Kononchuk, O. M. (2009). Technical prerequisites for geothermal ventilation of passive buildings. Lviv Polytechnic National University, Lviv. № 823 , pp. 281-285.

Sedaghat, A - Habibi, M - Hakkaki-Fard, A (2020) A novel ground thermal recovery system for horizontal ground heat exchangers in a hot climate, Energy Conversion and Management, 224, 113350.

Suszanowicz, D., \& Pietkun-Greber, I. (2017) The effectiveness of various types of ventilation on air quality in multi-family buildings. Ecological Chemistry and Engineering. A, 24(1), pp. 33-40.

Suszanowicz, D. (2018) Optimisation of heat loss through ventilation for residential buildings. Atmosphere, Recent Advances in Urban Ventilation Assessment and Flow Modelling 9(3), pp.148-157.

Ukraine Renewable Energy (2019) State Agency on Energy Efficiency and Energy Saving of Ukraine. Available at:

https:/ec.europa.eu/energy/sites/ener/files/documents/leshchyshyn_ua_saee_res_ukraine.pdf, (accessed at 20/02/2020).

Žandeckis, A. - Kḷaviṇa, K. - Dzikēvičs, M. - Kirsanovs, V. - Žogla, G. (2015) Solutions for Energy Efficient and Sustainable Heating of Ventilation Air: A Review. Journal of Engineering Science \& Technology Review, 8(3), pp. 98-111. 